\title{
Genetic variability in Peregrine Falcon populations of the Western Palaearctic region
}

\author{
Chiara Mengoni ${ }^{1}$, Iñigo Zuberogoitia ${ }^{2}$, Nadia $\mathrm{MuCCI}^{1}$, Giovanni \\ BOANO $^{3}$, Tomáš URBAN ${ }^{4}$, Enrico GuZzo ${ }^{5} \&$ Maurizio SARÁ ${ }^{5 *}$
}

Received: April 05, 2018 -Revised: September 07, 2018 -Accepted: September 09, 2018

This is a contribution submitted to the Proceedings of the World Conference on the Peregrine Falcon in Budapest in September 2017.

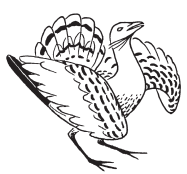

Mengoni, C., Zuberogoitia, I., Mucci, N., Boano, G., Urban, T. Guzzo, E. \& Sarà, M. 2018. Genetic variability in Peregrine Falcon populations of the Western Palaearctic region. - Ornis Hungarica 26(2): 12-26. DOI: 10.1515/orhu-2018-012

Abstract We analysed variation in ten polymorphic microsatellite loci and a portion of cytochrome $\mathrm{b}$ gene of mitochondrial DNA in 65 samples from four populations of Peregrine Falcon (Falco peregrinus peregrinus and F. p. brookei) breeding in Northern and Southern Italy, Northern Spain and the Czech Republic to assess genetic diversity in the poorly investigated Western Palearctic region. We added to our cytochrome $\mathrm{b}$ sequences a dataset of previously published mtDNA sequences of other populations and subspecies to outline genetic variation in the region on a worldwide basis. Regarding mtDNA we identified 12 haplotypes from our 65 Peregrine Falcon samples, nine of which were new and three already known. The $52 \%$ of our samples, including all Italian and Czech specimens, belonged to the previously identified HI haplotype, another $22 \%$ of the samples, most of which were from Sicily, showed the new $\mathrm{H} 1$ haplotype, while the remaining $26 \%$ of the sample partitioned among the other 10 haplotypes. Allelic patterns and genetic structuring of microsatellites were similar to those of other European populations. Genetic differentiation in both mtDNA and microsatellites loci is almost absent and it is not possible to distinguish geographical groups according to taxonomic designation at the subspecies level.

Keywords: Genetic structuring, Falco peregrinus brookei, microsatellites, mitochondrial DNA, Peregrine Falcon

Összefoglalás A kevéssé kutatott Nyugat-Palearktikus régióban vizsgáltuk a vándorsólyom két alfajába (Falco peregrinus peregrinus and F. p. brookei) tartozó négy populáció (Észak-, és Dél-Olaszország, Észak-Spanyolország, Cseh Köztársaság) genetikai diverzitását. Ehhez tíz mikroszatellit lókusz variabilitását és a mitokondriális DNS citokróm b génjének szekvenciáit elemeztük 65 mintában, négy populációból, melyek az észak-és dél-olaszországi, az észak-spanyol és a cseh populációkból származttak. Az általunk szekvenált citokróm b szekvenciákat együtt elemeztük a már korábban publikált más populációk és alfajok szekvenciáival, hogy a genetikai diverzitást a teljes elterjedési területen tudjuk vizsgálni. A saját 65 vándorsólyom mintákból 12 haplotípust azonosítottunk, melyek közül kilenc volt új és három már ismert. A mintáink 52\%-a, beleértve az összes olaszországi és csehországi egyedet, a már korábban publikált HI haplotípusba tartozott, a minták egy másik 22\%-a, amik föleg Szicíliából származtak, az új H1 haplotípusba, míg a maradék 26\% megoszlott a többi 10 haplotípus között. A mikroszatelliták vizsgálata alapján találtunk különbségeket az allélek megoszlásában, így van egyfajta genetikai mintázat más európai populációkkal összehasonlítva, ennek ellenére sem a mikroszatellit lókuszok, sem pedig a mitokondriális DNS alapján nem lehet egyértelmü földrajzi csoportokat elkülöníteni a taxonómiai besorolás szerinti alfaji szinten.

Kulcsszavak: genetikai térképezés, Falco peregrinus brookei, mikroszatelliták, mitokondriális DNS, vándorsólyom

${ }^{1}$ Unit for Conservation Genetics, Department for the Monitoring and Protection of the Environment and for Biodiversity Conservation, Italian Institute for Environmental Protection and Research (ISPRA), Via Cà Fornacetta 9, 40064 Ozzano dell'Emilia (Bo), Italy 


\section{E. Guzzo \& M. Sarà}

${ }^{2}$ Estudios Medioambientales Icarus - Logroño, Spain

${ }^{3}$ Museo Civico di Storia Naturale di Carmagnola, Torino, Italy

${ }^{4}$ Department of Animal Morphology, Physiology and Genetics, CEITEC, Faculty of Agri-Sciences, Mendel University in Brno, Czech Republic

${ }^{5}$ Section of Animal Biology, STEBICEF Department, Palermo University, Italy, e-mail: maurizio.sara@unipa.it

* corresponding author

\section{Introduction}

The Peregrine Falcon (Falco peregrinus) is a nearly-cosmopolitan species with a large phenotypic variability, currently described in 19 subspecies across the world (White et al. 2013a). After a massive decline and several regional extinctions in the second half of the $20^{\text {th }}$ century, the ban of organochlorine pesticides coupled with greater protection, reintroduction programmes and restrictions of illegal trading have stopped the species' decline and have boosted up the Peregrine Falcon populations of the Northern Hemisphere (Cade et al. 1988, White et al. 2013a).

The use of molecular markers that can be easily amplified by polymerase chain reaction (PCR) and then sequenced is nowadays a widespread tool for the reconstruction of phylogenetic relationships among avian taxa (Sibley 1994). The nucleotide sequence of the mitochondrial cytochrome $b$ gene was one of the first markers used in this field, and original contributes related to the phylogeny of Peregrine Falcon and its allied species in the Falconiformes group have been reported in Helbig et al. (1994) and Wink et al. (1998, 2000). Microsatellites, referred to as tandem repeats of short DNA sequences, are genetic markers that show a high level of variation and have been employed for studying avian population structure and systematics (Ellegren 1992, Bruford \& Wayne 1993, Nesje et al. 2000a). Actually, there are available several developed microsatellite markers specifically for the Scandinavian Peregrine Falcons, which were used to compare the population structure and genetic variability of F. p. peregrinus populations breeding in north Europe with some subspecies present in North America and Tasmania (Nesje et al. 2000b).

Molecular analyses of variable microsatellite markers and mitochondrial DNA supported the conservation actions taken in North Europe and North America (Nesje et al. 2000a, Tordoff \& Reding 2001, Jacobsen et al. 2008, Johnson et al. 2010, Ponnikas et al. 2017), and the investigation of the genetic relationships among many subspecies, including some of remote oceanic islands (Nesje et al. 2000b, Talbot et al. 2011, White et al. 2013b, Bell et al. 2014). In Mediterranean areas of Western Palaearctic region, corresponding to most of $F$. p. brookei range, the past population collapse was less extended. For instance, both in Italy (Schenk et al. 1985, Allavena \& Brunelli 2003) and Spain (Gainzarain et al. 2002) large populations (826-1048 breeding pairs in Italy, and 2384-2690 in Spain) fluctuated or increased locally and were threatened mostly by nest despoliation for illegal trading of eggs and chicks, and direct human persecution. As consequence, population structure and genetic variability of Peregrine Falcons living in these areas were poorly investigated. In this study, we characterize the genetic composition and structure of four populations breeding in North and South Italy, North Spain and the Czech Republic by using ten polymorphic microsatellites and a portion of cytochrome $\mathrm{b}$ gene of mitochondrial DNA. The Spanish population breeds in the F. p. 
brookei/F. p. peregrinus contact zone (Zuberogoitia et al. 2009), both the North Italian and the Czech populations breed within the F. p. peregrinus range, while the South Italian breeds within the F. p. brookei range (Bryndová et al. 2012, White et al. 2013a).

\section{Material and Methods}

We genotyped quills of nuchal feathers (e.g. Horváth et al. 2005) and muscle tissues of documented nest-site origin coming from 65 specimens: 9 from Northern Spain (Biscay), 8 from the Czech Republic, 5 from Northern Italy (Piedmont and Emilia), and 43 from Southern Italy ( 1 from Campania, continental Italy; 42 from the island of Sicily). One nestling from each nest site was used (Table 1). Feather samples were obtained from wild nestlings (Spain, Sicily, and the Czech Republic), while muscle tissues came from adult individuals found dead in different and well separated localities of North and continental Southern Italy. The sample from the Czech Republic is a subsample of wild Peregrine Falcons DNA already used in Bryndová et al. (2012).

We used ZR Genomic DNA II Kit ${ }^{\mathrm{TM}}$ for solid/liquid samples (Zymo Research) to extract and purify genomic DNA from samples. DNA samples were genotyped across 10 microsatellite markers originally designed for Falco peregrinus (Nesjie et al. 2000a): Fp13, Fp31, Fp46_1, Fp54, Fp79_4, Fp86_2, Fp89, Fp92_1, Fp107; and for Accipiter gentilis (Topinka $\&$ May 2004): Age5. We carried out two independent PCR replicates to check the absence of Allelic Drop Out (ADO) or false alleles (FA). Furthermore, we amplified and sequenced a $960 \mathrm{bp}$ long fragment of cytochrome $\mathrm{b}$ gene in mtDNA using a combinations of primer pairs (L14841-H15149, L15132-H15516, L15489-H15915) according to protocols described in Bell et al. (2014), to which refer for further details. In both cases we used the following PCR protocol: a first denaturation step at $94{ }^{\circ} \mathrm{C}$ for $3 \mathrm{~min} ; 35$ cycles at $94{ }^{\circ} \mathrm{C}$ for $40 \mathrm{~s}, 55^{\circ} \mathrm{C}$ for 40 $\mathrm{s}, 72{ }^{\circ} \mathrm{C}$ for $40 \mathrm{~s}$; and a final step at $60^{\circ} \mathrm{C}$ for $30 \mathrm{~min}$. PCR products were then processed in an ABI 3130XL sequencer. We used Genalex 6.1 (Peakall \& Smouse 2006) to estimate the allele frequencies by locus and population, mean number of alleles per locus (NA), observed $\left(\mathrm{H}_{\mathrm{o}}\right)$ and expected unbiased $\left(\mathrm{UH}_{\mathrm{e}}\right)$ heterozygosity and the related chi-square test for deviations from Hardy-Weinberg equilibrium (HWE). Pairwise $\mathrm{F}_{\mathrm{ST}}$ (Weir \& Cockerham 1984), which is a measure of among-population variance in allelic frequencies, and principal coordinate analysis (PCoA), which gives an ordination of all data points based on a covariance matrix with microsatellite data standardization, were calculated using GENETIX 4.05 (Belkhir et al. 19962004) and FSTAT (Goudet 2001). We aligned the mtDNA sequences of our samples together with 17 haplotype sequences of $F$. peregrinus, and one Sharp-shinned Hawk (Accipiter striatus) sequence retrieved from GenBank and published by Bell et al. (2014). The latter was used as outgroup as in Bell et al. (2014). We aligned the mtDNA sequences with Bioedit (Hall 1999), then we identified the haplotypes using Dnasp 5 (Librado \& Rosas al. 2009). We clustered a Tamura and Nei genetic distance matrix using the neighbour-joining procedure in Mega 5 (Tamura et al. 2011) with internode bootstrap values determined after 1000 resampling steps. Eventually, we reconstructed the phylogenetic relationships among the mtDNA haplotypes using median-joining networks in Network 4.6 (Bandelt et al. 1999). 


\section{E. Guzzo \& M. Sarà}

Table 1. List of specimens considered in the study of genetic diversity of the Western Palaearctic Peregrine Falcons. Sample: $\mathrm{MU}=$ muscle tissue, $\mathrm{FE}=$ feather; $\mathrm{mtDNA}$ haplotypes $\mathrm{HE}$ (GeneBank Accession No. KP863007), HI (KP863006) and HL (KP863014) described in Bell et al. 2014, while haplotypes H1-H9 found in the present study (MH837632-MH837640)

1.táblázat $\mathrm{A}$ vándorsólyom egyedek táblázata, amelyek mintáit használtuk a genetikai diverzitás felmérésére a nyugat-paleakrtikusi elterjedési területen. Sample: $\mathrm{MU}=$ izomszövet, $\mathrm{FE}=$ toll; Bell et al. (2014) által publikált mtDNS haplotípusok: HE, HI és HL, ebben a vizsgálatban talált új haplotípusok: H1-H9

\begin{tabular}{|c|c|c|c|c|c|c|c|c|}
\hline Id Lab & Taxon & Area & Region & $\begin{array}{c}\text { Sampling } \\
\text { year }\end{array}$ & Sex & Age & Sample & $\begin{array}{c}\text { Mt DNA } \\
\text { haplotype }\end{array}$ \\
\hline FPE62 & F.p.brookei & South Italy & Campania & 2005 & M & NA & MU & $\mathrm{HI}$ \\
\hline FPE63 & F.p.brookei & North Italy & Emilia & 2010 & $M$ & NA & MU & $\mathrm{HI}$ \\
\hline FPE66 & F.p.peregrinus & North Italy & Piedmont & 2012 & M & SAD & MU & $\mathrm{HI}$ \\
\hline FPE69 & F.p. peregrinus & North Italy & Piedmont & 2007 & M & JUV & MU & $\mathrm{HI}$ \\
\hline FPE71 & F.p.peregrinus & North Italy & Piedmont & 2010 & $\mathrm{~F}$ & $A D$ & MU & $\mathrm{HI}$ \\
\hline FPE72 & F.p.peregrinus & North Italy & Piedmont & 2010 & M & NA & MU & $\mathrm{HI}$ \\
\hline FPE76 & F.p.peregrinus & Czech Republic & Central & 2011 & $M$ & JUV & $\mathrm{FE}$ & $\mathrm{HI}$ \\
\hline FPE77 & F.p.peregrinus & Czech Republic & Central & 2011 & $\mathrm{~F}$ & JUV & $\mathrm{FE}$ & $\mathrm{HI}$ \\
\hline FPE78 & F.p.peregrinus & Czech Republic & $\begin{array}{l}\text { Ústí nad } \\
\text { Labem }\end{array}$ & 2010 & M & JUV & FE & $\mathrm{HI}$ \\
\hline FPE79 & F.p.peregrinus & Czech Republic & Central & 2011 & $\mathrm{~F}$ & JUV & FE & $\mathrm{HI}$ \\
\hline FPE80 & F.p.peregrinus & Czech Republic & $\begin{array}{l}\text { Hradec } \\
\text { Králové }\end{array}$ & 2011 & $\mathrm{~F}$ & JUV & FE & $\mathrm{HI}$ \\
\hline FPE81 & F.p.peregrinus & Czech Republic & Central & 2010 & M & JUV & FE & $\mathrm{HI}$ \\
\hline FPE83 & F.p.peregrinus & Czech Republic & $\begin{array}{l}\text { Ústínad } \\
\text { Labem }\end{array}$ & 2010 & $\mathrm{~F}$ & JUV & $\mathrm{FE}$ & $\mathrm{HI}$ \\
\hline FPE85 & F.p.peregrinus & Czech Republic & Central & 2011 & $\mathrm{~F}$ & JUV & $\mathrm{FE}$ & $\mathrm{HI}$ \\
\hline FBI19 & F.p.brookei & South Italy & Sicily & 2017 & M & JUV & $\mathrm{FE}$ & $\mathrm{H} 1$ \\
\hline FBI6 & F.p.brookei & South Italy & Sicily & 2017 & $M$ & JUV & $\mathrm{FE}$ & $\mathrm{HI}$ \\
\hline $\mathrm{FBI7}$ & F.p.brookei & South Italy & Sicily & 2017 & M & SAD & $\mathrm{FE}$ & $\mathrm{H} 1$ \\
\hline FPE1 & F.p.brookei & South Italy & Sicily & 2017 & $\mathrm{~F}$ & JUV & $\mathrm{FE}$ & $\mathrm{H} 1$ \\
\hline FPE102 & F.p.brookei & South Italy & Sicily & 2017 & $\mathrm{~F}$ & JUV & $\mathrm{FE}$ & $\mathrm{H} 1$ \\
\hline FPE105 & F.p.brookei & South Italy & Sicily & 2017 & $M$ & JUV & $\mathrm{FE}$ & $\mathrm{H} 1$ \\
\hline FPE13 & F.p.brookei & South Italy & Sicily & 2016 & $M$ & JUV & $\mathrm{FE}$ & $\mathrm{H} 6$ \\
\hline FPE15 & F.p.brookei & South Italy & Sicily & 2016 & M & JUV & $\mathrm{FE}$ & $\mathrm{H} 1$ \\
\hline FPE16 & F.p.brookei & South Italy & Sicily & 2016 & $\mathrm{~F}$ & JUV & $\mathrm{FE}$ & $\mathrm{HE}$ \\
\hline FPE20 & F.p.brookei & South Italy & Sicily & 2016 & $M$ & $A D+$ & $\mathrm{FE}$ & $\mathrm{H} 7$ \\
\hline FPE47 & F.p.brookei & South Italy & Sicily & 2017 & M & $A D+$ & $\mathrm{FE}$ & $\mathrm{HI}$ \\
\hline FPE48 & F.p.brookei & South Italy & Sicily & 2017 & $\mathrm{~F}$ & SAD & $\mathrm{FE}$ & $\mathrm{HL}$ \\
\hline FPE49 & F.p.brookei & South Italy & Sicily & 2017 & M & $A D+$ & $\mathrm{FE}$ & $\mathrm{HI}$ \\
\hline FPE5 & F.p.brookei & South Italy & Sicily & 2016 & $\mathrm{~F}$ & JUV & $\mathrm{FE}$ & $\mathrm{H} 3$ \\
\hline FPE50 & F.p.brookei & South Italy & Sicily & 2017 & $\mathrm{~F}$ & $A D+$ & $\mathrm{FE}$ & $\mathrm{HI}$ \\
\hline
\end{tabular}




\begin{tabular}{|c|c|c|c|c|c|c|c|c|}
\hline Id Lab & Taxon & Area & Region & $\begin{array}{c}\text { Sampling } \\
\text { year }\end{array}$ & Sex & Age & Sample & $\begin{array}{c}\text { Mt DNA } \\
\text { haplotype }\end{array}$ \\
\hline FPE51 & F.p.brookei & South Italy & Sicily & 2017 & $\mathrm{M}$ & JUV & $\mathrm{FE}$ & $\mathrm{HE}$ \\
\hline FPE52 & F.p.brookei & South Italy & Sicily & 2017 & $\mathrm{~F}$ & SAD & $\mathrm{FE}$ & $\mathrm{HL}$ \\
\hline FPE53 & F.p.brookei & South Italy & Sicily & 2017 & $\mathrm{~F}$ & SAD & $\mathrm{FE}$ & $\mathrm{H} 4$ \\
\hline FPE54 & F.p.brookei & South Italy & Sicily & 2017 & $\mathrm{~F}$ & JUV & $\mathrm{FE}$ & $\mathrm{HL}$ \\
\hline FPE55 & F.p.brookei & South Italy & Sicily & 2017 & $M$ & SAD & $\mathrm{FE}$ & $\mathrm{HI}$ \\
\hline FPE56 & F.p.brookei & South Italy & Sicily & 2017 & $\mathrm{~F}$ & JUV & $\mathrm{FE}$ & $\mathrm{H} 8$ \\
\hline FPE57 & F.p.brookei & South Italy & Sicily & 2017 & $M$ & JUV & $\mathrm{FE}$ & $\mathrm{HI}$ \\
\hline FPE58 & F.p.brookei & South Italy & Sicily & 2017 & $\mathrm{M}$ & SAD & $\mathrm{FE}$ & H5 \\
\hline FPE59 & F.p.brookei & South Italy & Sicily & 2017 & $M$ & JUV & $\mathrm{FE}$ & $\mathrm{HI}$ \\
\hline FPE6 & F.p.brookei & South Italy & Sicily & 2016 & $\mathrm{~F}$ & JUV & $\mathrm{FE}$ & $\mathrm{HI}$ \\
\hline FPE60 & F.p.brookei & South Italy & Sicily & 2017 & $\mathrm{M}$ & JUV & $\mathrm{FE}$ & $\mathrm{H} 1$ \\
\hline FPE61 & F.p.brookei & South Italy & Sicily & 2016 & $\mathrm{M}$ & JUV & $\mathrm{FE}$ & $\mathrm{H} 9$ \\
\hline FPE64 & F.p.brookei & South Italy & Sicily & 2016 & $\mathrm{~F}$ & $A D+$ & $\mathrm{FE}$ & $\mathrm{HI}$ \\
\hline FPE65 & F.p.brookei & South Italy & Sicily & 2016 & $\mathrm{~F}$ & JUV & $\mathrm{FE}$ & $\mathrm{H} 9$ \\
\hline FPE67 & F.p.brookei & South Italy & Sicily & 2005 & $\mathrm{~F}$ & $A D+$ & $\mathrm{FE}$ & $\mathrm{HI}$ \\
\hline FPE68 & F.p.brookei & South Italy & Sicily & 2005 & $\mathrm{~F}$ & - & $\mathrm{FE}$ & $\mathrm{H} 1$ \\
\hline FPE70 & F.p.brookei & South Italy & Sicily & 2017 & $\mathrm{~F}$ & SAD & $\mathrm{FE}$ & $\mathrm{HI}$ \\
\hline FPE74 & F.p.brookei & South Italy & Sicily & 2016 & $\mathrm{M}$ & SAD & $\mathrm{FE}$ & $\mathrm{H} 1$ \\
\hline FPE75 & F.p.brookei & South Italy & Sicily & 2017 & $\mathrm{~F}$ & JUV & $\mathrm{FE}$ & $\mathrm{HI}$ \\
\hline FPE86 & F.p.brookei & South Italy & Sicily & 2017 & $\mathrm{~F}$ & JUV & $\mathrm{FE}$ & $\mathrm{HI}$ \\
\hline FPE88 & F.p.brookei & South Italy & Sicily & 2017 & - & JUV & $\mathrm{FE}$ & $\mathrm{H} 1$ \\
\hline FPE89 & F.p.brookei & South Italy & Sicily & 2017 & $\mathrm{M}$ & JUV & $\mathrm{FE}$ & $\mathrm{H} 1$ \\
\hline FPE9 & F.p.brookei & South Italy & Sicily & 2016 & $M$ & JUV & FE & $\mathrm{H} 1$ \\
\hline FPE94 & F.p.brookei & South Italy & Sicily & 2017 & $M$ & JUV & $\mathrm{FE}$ & $\mathrm{H} 6$ \\
\hline FPE96 & F.p.brookei & South Italy & Sicily & 2017 & $M$ & JUV & $\mathrm{FE}$ & $\mathrm{H} 1$ \\
\hline FPE98 & F.p.brookei & South Italy & Sicily & 2017 & $\mathrm{~F}$ & JUV & $\mathrm{FE}$ & $\mathrm{HI}$ \\
\hline FPE99 & F.p.brookei & South Italy & Sicily & 2017 & $\mathrm{~F}$ & JUV & $\mathrm{FE}$ & $\mathrm{H} 1$ \\
\hline FPE21 & F.p.brookei & Spain & Biscay & 2016 & $\mathrm{~F}$ & JUV & $\mathrm{FE}$ & $\mathrm{HI}$ \\
\hline FPE25 & F.p.brookei & Spain & Biscay & 2016 & $\mathrm{M}$ & JUV & $\mathrm{FE}$ & $\mathrm{HI}$ \\
\hline FPE27 & F.p.brookei & Spain & Biscay & 2016 & $\mathrm{M}$ & JUV & $\mathrm{FE}$ & $\mathrm{HI}$ \\
\hline FPE30 & F.p.brookei & Spain & Biscay & 2016 & $\mathrm{~F}$ & JUV & $\mathrm{FE}$ & $\mathrm{HI}$ \\
\hline FPE32 & F.p.brookei & Spain & Biscay & 2016 & $\mathrm{~F}$ & JUV & FE & $\mathrm{HE}$ \\
\hline FPE33 & F.p.brookei & Spain & Biscay & 2016 & $\mathrm{~F}$ & JUV & $\mathrm{FE}$ & $\mathrm{HE}$ \\
\hline FPE35 & F.p.brookei & Spain & Biscay & 2016 & $\mathrm{M}$ & JUV & $\mathrm{FE}$ & $\mathrm{HI}$ \\
\hline FPE37 & F.p.brookei & Spain & Biscay & 2016 & $\mathrm{~F}$ & JUV & $\mathrm{FE}$ & $\mathrm{HI}$ \\
\hline FPE41 & F.p.brookei & Spain & Biscay & 2016 & $\mathrm{M}$ & JUV & $\mathrm{FE}$ & $\mathrm{H} 2$ \\
\hline
\end{tabular}




\section{E. Guzzo \& M. Sarà}

\section{Results}

\section{Mitochondrial DNA}

The analysis of the four populations of Peregrine Falcons revealed a low inter-population genetic variability between the considered subspecies (peregrinus and brookei), albeit an insular effect can be observed based on the genetic pattern of Sicilian population. We identified 12 haplotypes from the 65 Peregrine Falcon samples, nine of which were new haplotypes found for the first time and coded from $\mathrm{H} 1$ to $\mathrm{H} 9$, while the other three have been already described by Bell et al. (2014) (Table 1). The 52\% of our samples $(\mathrm{n}=34)$ belonged to the previously published HI haplotype, and another $22 \%(\mathrm{n}=14)$ of the samples showed the new H1 haplotype, while the remaining $26 \%$ of the samples partitioned among the other 10 haplotypes. Both the whole Italian and the Czech samples belonged to the HI haplotype, while the Spanish Peregrine Falcons split up among two Bell's haplotypes HI $(n=6)$ and $\mathrm{HE}(\mathrm{n}=2)$, and one new H2 haplotype $(\mathrm{n}=1)$. The Sicilian Peregrine Falcons showed the largest haplotype diversity as the 42 individuals split up among Bell's and new haplotypes unique for this population. The already identified Bell's haplotypes found in Sicily are: $\mathrm{HI}(\mathrm{n}=14), \mathrm{HL}(\mathrm{n}=3)$ and $\mathrm{HE}(\mathrm{n}=2)$, whereas the new ones are: $\mathrm{H} 1(\mathrm{n}=14)$ and from $\mathrm{H} 3$ to $\mathrm{H} 9$, all these latter with $\mathrm{n}=1$, but $\mathrm{H} 6$ and $\mathrm{H} 9$ with $\mathrm{n}=2$ individuals.

The neighbour-joining network of the haplotypes found in a $960 \mathrm{bp}$ fragment of cyt b mtDNA gene and considered in this study (Figure 1) reproduces the large heterogeneity between the geographic origin and the taxonomic designation of Peregrine Falcons. For instance, haplotype HI, the most shared among individuals, occurs across Canada (tundrius) and Europe (peregrinus, brookei). Yet, in our sample this haplotype assembles Sicilian and South Italian Peregrines expected to be brookei, together with Spanish specimens from the brookei/peregrinus border zone of Biscay, plus two more Spanish brookei samples present in Bell et al. (2014). Such a brookei group of samples anyway cluster with North Italian and Czech Republic individuals expected to belong to the nominate subspecies peregrinus. 14 Sicilian samples were grouped in the new haplotype H1, which indeed was the second in order of frequency among the found haplotypes. Third in order of frequency comes the haplotype HQ, which is separated by one mutational step from H1, and is definitely the most cosmopolitan one, as groups together some Sicilian and Biscay Peregrine Falcons with the Australian (macropus), the Argentinian (cassini), the American (tundrius, anatum), the African (minor) and others subspecies with unknown geographic origin (babilonycus, pelegrinoides).

\section{Microsatellites}

The genetic intra-population diversity based on microsatellite analysis of 65 unrelated specimens (42 from Sicily, 9 from Spain, 8 from the Czech Republic, 6 from Italy) has been reported in Figure 2 and Table 2. All loci were polymorphic. The number of alleles per locus ranges from 1 to 11 (in Spain: 2-8, in the Czech Republic: 2-7, in Italy: 1-8, in Sicily: 2-11) with a total mean $\pm \mathrm{SE}$ of $3.65 \pm 0.319$ alleles over the four populations, the highest number of different alleles was found in Sicily (Figure 2). Average of allelic richness in the four population was 3.24, ranging from the minimum 3.03 in the Czech Republic to the maximum 


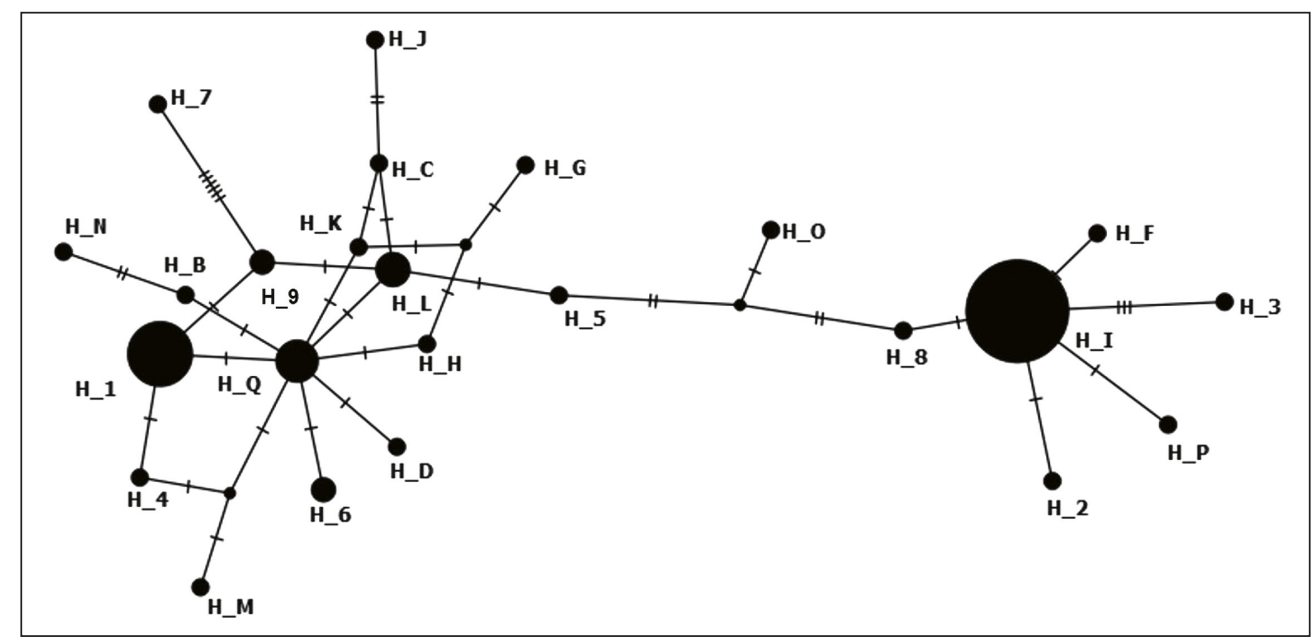

Figure 1. Haplotype neighbour-joining network of $960 \mathrm{bp}$ segment of cytochrome b gene of mtDNA based on the 65 Peregrine Falcons considered in this study (the 9 new haplotypes are marked from $\mathrm{H} 1$ to $\mathrm{H} 9$ ) and the Bell et al. (2014) samples (15 haplotypes marked with $\mathrm{H}$ followed by letter) retrieved from GenBank. Three Bell's haplotypes (HI, HL and HE) were also found in our sample. The size of the nodes indicates the relative frequency of the corresponding haplotype in the dataset, as listed in Table 1. Small tracts show the mutational steps occurring between adjacent haplotypes

1.ábra A mtDNS citokróm b génjének 960 bázispár hosszú része alapján készült haplotípus hálózat. H1-H9: a 65 vándorsólyom minta alapján általunk talált haplotípusok, $\mathrm{H}$-betűkkel jelölve: Bell et al. (2014) által közölt haplotípusok a GenBank-ból származó szekvenciái alapján. A mintáinkban a Bell et al. (2014) által közölt haplotípusok közül hármat találtunk meg (HI, HL and HE). A nóduszok méretei megfelelnek a haplotípusok relatív gyakoriságainak az 1. táblázatban közölt mintákban. Az ágakon lévő kicsi vonalak a mutációs lépések számát jelölik a haplotípusok között

3.40 in Italy. All populations have a comparable mean of different alleles with a frequency $\geq 5 \%$, as well as of effective alleles, indeed the mean of these latter is slightly lower in the Czech Republic than in the other populations (Figure 2). Contrariwise, Sicily has the highest mean of unique alleles with respect to the other populations (Figure 2), depending from the absolute number of exclusive alleles $(\mathrm{n}=10)$ found in the island, with respect to the Czech Republic $(n=3)$, Spain and Italy (both $n=2)$. Besides, Shannon diversity index, the observed $\left(\mathrm{H}_{\mathrm{o}}\right)$, expected $\left(\mathrm{H}_{\mathrm{e}}\right)$ and unbiased expected heterozygosity $\left(\mathrm{UH}_{\mathrm{e}}\right)$ values were comparable among the four populations, with a relatively lower Shannon diversity value, and $\mathrm{UH}_{\mathrm{e}}$ of the Czech population (Table 2). Fixation index values are negative for Italy and the Czech Republic and positive for Spain and Sicily. This latter has the relatively higher reduction in heterozygosity when compared to Hardy-Weinberg expectations (Table 2). As a matter of fact, none of the populations shows significant differences from Hardy-Weinberg equilibrium, with a fixation index ranging around a zero average value $(-0.031)$.

As regards to genetic structuring, we have found a low amount of non-random mating in all populations, which shows $\mathrm{F}_{\text {IS }}$ values (after 1000 allelic permutations averaged over the ten loci in each population) negative in Czech Republic $(-0.056)$ and positive in the others three areas $($ Spain $=0.082$, Italy $=0.071$, Sicily $=0.053)$. P-values were not significant for all pairwise comparisons between the $\mathrm{F}_{\mathrm{IS}}$ values. 


\section{E. Guzzo \& M. Sarà}

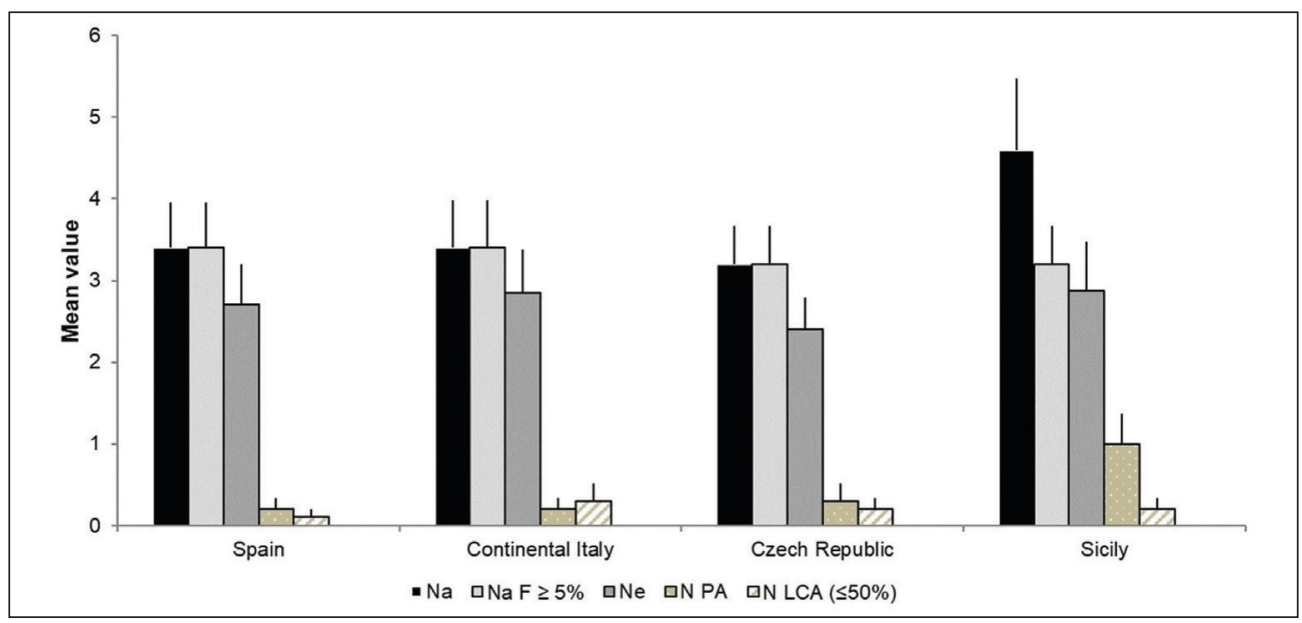

Figure 2. Allelic pattern across populations of Peregrine Falcon in areas of the Western Palaearctic. $\mathrm{Na}=\mathrm{N}$ of different alleles; $\mathrm{Na}(\mathrm{F} \geq 5 \%)=\mathrm{N}$ of different alleles with a frequency $\geq 5 \% ; \mathrm{Ne}=\mathrm{N}$ of effective alleles; $\mathrm{N}$ PA $=\mathrm{N}$ of alleles unique to a single population; $\mathrm{N} L C A(\leq 50 \%)=\mathrm{N}$ of locally common alleles with a frequency of $\geq 5 \%$ found in $50 \%$ or fewer populations

2. ábra Vándorsólyom-populációk allél-mintázatai a Nyugat-Palearktiszban. $\mathrm{Na}=$ különböző allélek száma; $\mathrm{Na}(\mathrm{F} \geq 5 \%)$ = különböző allélek száma, melyek gyakorisága $\geq 5 \%$; Ne effektív allélek száma; N PA = csak egy populációban előforduló egyedi allélek száma; N LCA ( $\leq 50 \%)=$ lokálisan azonos allélek száma, melyek gyakorisága $\geq 5 \%$ csak a populációk 50\%-ban, vagy kevesebben megtalálható

Table 2. Intra-population diversity and heterozygosity mean $( \pm \mathrm{SE})$ values based on microsatellite analysis of 65 unrelated Peregrine Falcons. Mean over loci for each Peregrine Falcon population. $\mathrm{SI}=$ Shannon index; $\mathrm{H}_{\mathrm{o}}=$ Observed Heterozygosity; $\mathrm{H}_{\mathrm{e}}=$ Expected Heterozygosity; $\mathrm{UH}_{\mathrm{e}}=$ Unbiased expected Heterozygosity; $\mathrm{FI}=$ Fixation index

2. táblázat Populáción belüli diverzitás és átlagos heterozigócia (átlag (mean) \pm standard hiba (SE)) értékek a 65 nem rokon vándorsólyom mintáinak mikroszatellita elemzése alapján. A táblázat a lókuszok átlagos értékeit mutatja az egyes populációkban (Spain-spanyol, Continental Italy-kontinentális olasz, Czech Republic-cseh, Sicily-szicíliai, Total-összes). SI = Shannon index; $\mathrm{H}_{\mathrm{o}}=$ megfigyelt heterozigócia; $\mathrm{H}_{\mathrm{e}}=$ várt heterozigócia; $\mathrm{UH}_{\mathrm{e}}=$ torzítatlan várt heterozigócia; $\mathrm{Fl}$ = fixációs index

\begin{tabular}{|l|c|c|c|c|c|c|}
\hline & & SI & Ho & He & UHe & FI \\
\hline Spain & Mean & 0.973 & 0.533 & 0.546 & 0.578 & 0.011 \\
\hline & SE & 0.146 & 0.079 & 0.061 & 0.065 & 0.091 \\
\hline Continental Italy & Mean & 0.994 & 0.567 & 0.556 & 0.606 & -0.004 \\
\hline & SE & 0.161 & 0.097 & 0.073 & 0.079 & 0.096 \\
\hline Czech Republic & Mean & 0.902 & 0.580 & 0.517 & 0.552 & -0.162 \\
\hline & SE & 0.123 & 0.048 & 0.051 & 0.055 & 0.081 \\
\hline Sicily & Mean & 1.079 & 0.549 & 0.572 & 0.579 & 0.035 \\
\hline & SE & 0.154 & 0.048 & 0.050 & 0.051 & 0.037 \\
\hline Total & Mean & 0.987 & 0.557 & 0.548 & 0.579 & -0.031 \\
\hline & SE & 0.071 & 0.034 & 0.029 & 0.031 & 0.040 \\
\hline
\end{tabular}


Pairwise values of $\mathrm{F}_{\mathrm{ST}}$ statistics, as obtained from FSTAT (above diagonal values) and GENETIX (below diagonal values) software have been reported in Table 3. We reported results from both software for a careful approach as GENETIX implements a permutation-based procedure alternative to jack-knifing used in FSTAT to calculate statistical inference. According to both software, differences among populations are small and only the values between the Czech Republic and Sicily are statistically significant (marked with asterisk in Table 3), while only GENETIX recorded significant values also between Spain and the Czech Republic.

The analysis of molecular variance (AMOVA) shows that differences between the four populations are marginal as they explained only $3.3 \%$ of the total genetic variation, while intra-population difference was the $96.7 \%$ of the total genetic variation (Table 4).

Eventually, the scatter of Principal Coordinates Analysis (Figure 3) shows how all the specimens spread across the first two factor axes (F1 and F2) that give a measure of the variance accounted for by the corresponding coordinates (eigenvectors), evidencing the lack of genetic structuring among the four studied Peregrine Falcon populations. Such a lack of genetic structuring keeps even considering the third axis (F3). The cumulative percentage of variance explained by the first 3 axes is equivalent to $31.36 \%$.

Table 3. Pairwise $F_{S T}$ statistics comparison between populations, as obtained from FSTAT (above diagonal values) and GENETIX (below diagonal values) software. Values marked with asterisk are statistically significant $(P \leq 0.05)$

3. táblázat Páronkénti $\mathrm{F}_{\mathrm{ST}}$-értékek a populációk (Spain-spanyol, Continental Italy-kontinentális olasz, Czech Republic-cseh, Sicily-szicíliai) összehasonlítására az FSTAT (diagonális feletti értékek) és a GENETIX (diagonális alatti értékek) programmal számolva. A csillagozott értékek statisztikailag szignifikánsak $(P \leq 0.05)$

\begin{tabular}{|l|c|c|c|c|}
\hline & Spain & Continental Italy & Czech Republic & Sicily \\
\hline Spain & - & -0.0173 & 0.0299 & 0.0151 \\
\hline Continental Italy & 0.4083 & - & -0.0022 & 0.0092 \\
\hline Czech Republic & $0.0083^{*}$ & 0.1333 & - & $0.0317^{*}$ \\
\hline Sicily & 0.0250 & 0.0750 & $0.0083^{*}$ & - \\
\hline
\end{tabular}

Table 4. Analysis of molecular variance table showing the low differentiation among the populations with respect to the large individual variability. The related PhiPT statistics is $=0.033$, with $\mathrm{P}=0.022$. The probability $\mathrm{P}$ (random $\geq$ data) for PhiPT is based on standard permutations across the full data set

4. táblázat A molekuláris variancia analízis táblázata, ami kevés variabilitást mutat a populációk között (Inter-population), összehasonlítva a nagy variabilitással a populációkon belül (Intra-population). A PhiPT érték $=0.033$, és a hozzátartozó P-érték $=0.022$. A PhiPT P-értkétt (random $\geq$ adat) standard permutációval számítottuk ki a teljes adathalmazra. df: szabadsági fok, SS: eltérés-négyzetösszeg, MS: eltérés-négyzetösszeg átlaga, Estimated Variance: becsült variancia

\begin{tabular}{|l|c|c|c|c|c|}
\hline \multicolumn{1}{|c|}{ Source } & df & SS & MS & $\begin{array}{c}\text { Estimated } \\
\text { Variance }\end{array}$ & $\begin{array}{c}\text { Estimated } \\
\text { Variance (\%) }\end{array}$ \\
\hline Inter-population & 3 & 25.688 & 8.563 & 0.207 & 3.3 \\
\hline Intra-population & 61 & 374.405 & 6.138 & 6.138 & 96.7 \\
\hline Total & 64 & 400.092 & & 6.345 & 100 \\
\hline
\end{tabular}




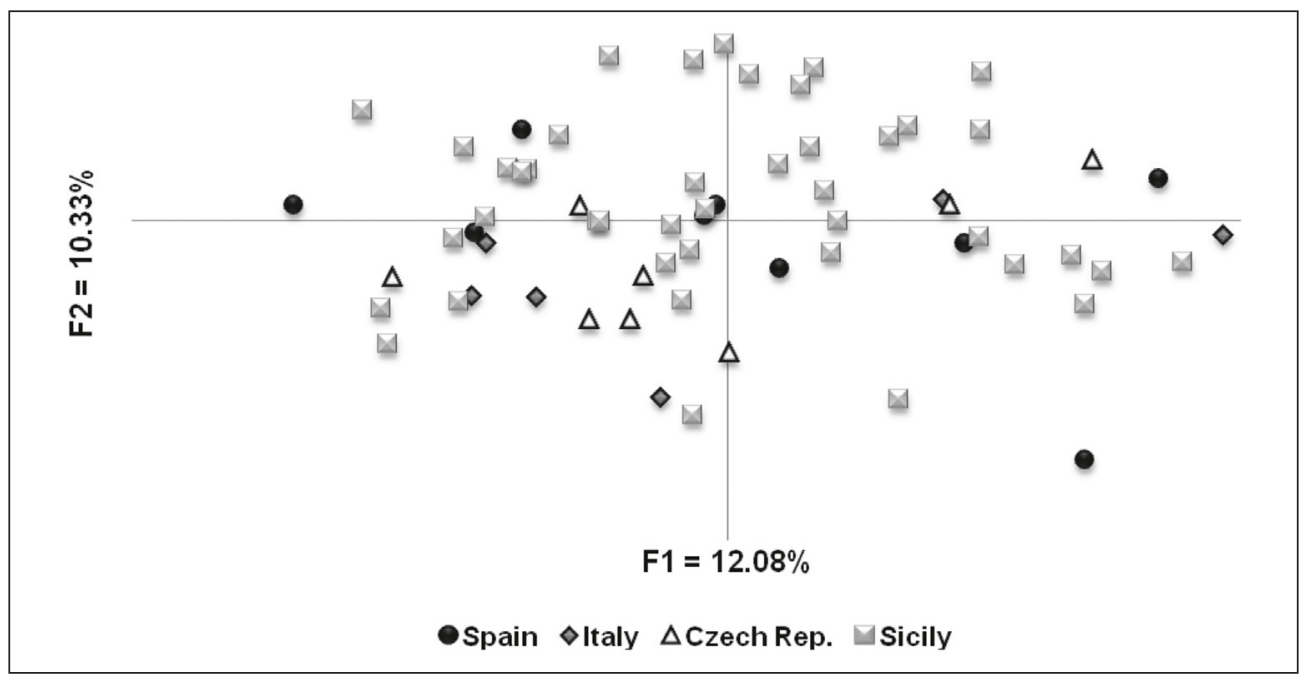

Figure 3. Scatter of the ordination method (Principal Coordinates Analysis by covariance matrix with data standardization) used to detect similarities of microsatellite data among the 65 unrelated Peregrine Falcons breeding in the four populations of Western Palaearctic. F1 and F2 are the factor axes that account for percentage of variation among specimens. No geographic grouping emerges from the scatter

3. ábra Főkomponens-analízis eredménye (PCoA) kovariancia mátrix alapján 65 nem rokon vándorsólyom minta adatait standardizálva a négy nyugat-palearktikus populációból

\section{Discussion}

We reported here for the first time molecular data from wild Peregrine Falcons living in Sicily, continental Italy and Northern Spain (Biscay). Low sample sizes in some of the considered populations might affect some results, as likely occurs for the higher Shannon diversity index of the Sicilian population, which had also the larger sample size. Despite this limitation, the estimation of intra-population diversity and allelic patterns provided an adequate genetic condition in the Spanish and Italian studied populations as the low-medium number of alleles and medium level of observed heterozygosity values were observed, but coupled with statistically not significant $\mathrm{F}_{\mathrm{IS}}$ values and departure from $\mathrm{HW}$ equilibrium. These data fall within the species' variability range as they are consistent to other Peregrine Falcon populations. For instance, Nesje et al. (2000a) found 2-11 alleles per locus with a mean \pm SE of $4.25 \pm 0.81$, mean $\pm \mathrm{SE}_{\mathrm{o}}$ value was equal to $0.452 \pm 0.080$ and $\mathrm{H}_{\mathrm{e}}$ was $0.512 \pm 0.073$ when examining genetic relationships among Peregrine Falcon populations in Southern Norway. In a much larger comparison of subspecies across the world, Nesje et al. (2000b) found 3-18 alleles per locus with $\mathrm{H}_{\mathrm{o}}$ ranging from 0.405 to 0.490 in all populations (except the Tasmanian with $\left.\mathrm{H}_{\mathrm{o}}=0.146\right)$. Jacobsen et al. (2008) comparing Southern Scandinavian and Northern Fennoscandic populations with different origin have found the $\mathrm{H}_{\mathrm{o}}$ to decrease from 0.53 \pm 0.07 in the historical population to $0.46 \pm 0.08$ in the reintroduced population. Likewise, the $H_{e}$ value's range was from $0.56 \pm 0.07$ in the historical to $0.50 \pm 0.07$ in the reintroduced population, anyway both heterozygosity decreases were not statistically significant. 
The complete dataset $(n=30)$ of wild Peregrine Falcons that Bryndová et al. (2012) have analysed gave slight different values with respect to the subsample $(n=8)$ considered here (Table 2). For instance, the mean $\mathrm{H}_{\mathrm{o}}$ was 0.546 , while the mean $\mathrm{H}_{\mathrm{e}}$ was 0.632 , and the allelic richness per locus ranged from 2.69 to 6.51 in the complete dataset. In addition, the whole Czech sample showed deviation from Hardy-Weinberg equilibrium in the form of heterozygote excess in the locus fp31, besides to a significant higher inbreeding coefficients $\mathrm{F}_{\text {IS }}$.

As regard the genetic structuring, we have found a low amount of non-random mating comparable to the historic Scandinavian population $\left(\mathrm{F}_{\mathrm{IS}}=0.08\right.$ in Jacobsen et al. 2008) and quite less than contemporary reintroduced wild populations $\left(\mathrm{F}_{\mathrm{IS}}=0.14\right.$ in Jacobsen et al. 2008 and $\mathrm{F}_{\mathrm{IS}}=0.139$ in Bryndová et al. 2012). The relatively higher $\mathrm{F}_{\mathrm{IS}}$ value in our samples was found in the Biscay population from Spain. It is enquiring that the signal of non-random mating among individuals, although low, is larger in a continental than in the insular population of Sicily. Interchange of adults in the Biscay population was documented within a radius of about $360 \mathrm{~km}$ (Zuberogoitia et al. 2009), a value that would maintain genetic connections with other Spanish and South-western French populations. It remains an open question whether such a non-random mating signal could be depending by chance from the specific sample here used, or from the peculiar condition of the Biscay population, at the border between the Spanish 'brookei' and the French 'peregrinus' ranges (Zuberogoitia et al. 2009). Otherwise, first investigation on natal dispersal has not yet recorded emigration from Sicily (see Bondì et al. 2018), though we cannot still exclude immigration from continental Italy. This condition goes hand in hand with the large number of exclusive alleles found in the Sicilian falcons, so to allow supposing a quite close population. If this would be the case, the population of Peregrine Falcons in this island, currently estimated at 240-250 pairs (see Bondì et al. 2018), would be large enough to limit non-random mating among individuals.

Despite the significant $\mathrm{F}_{\mathrm{ST}}$ differences between the Sicilian and the Czech populations, and also between the Spanish and the Czech based on only the GENETIX results, the AMOVA showed no differentiation among populations, with only a $3.3 \%$ of inter-population genetic variation. Similarly, Jacobsen et al. (2008) showed that differences between their four Scandinavian populations explained only $5 \%$ of the total genetic variation.

The low differentiation among populations is confirmed yet by the analysis of cytochrome b mitochondrial DNA sequences that produced a haplotype network, which was not concordant with geographic origin and taxonomic designation of the specimens. Previous works (White et al. 2013a, Bell et al. 2014, Johnson et al. 2017) have already noted such a discrepancy, suggesting that historical and recent dispersal, combined with rapid morphological evolution, could have contributed to the lack of phylogenetic concordance between mitochondrial DNA variation and geographic origin of the Peregrine Falcon. Both the Biscay and Sicilian populations could well describe this situation. The former has been suggested to show a character introgression with the close French $F$. p. peregrinus population that would produce variable phenotypes (Zuberogoitia et al. 2009) and the signals of non-random mating would stabilize pairs maintaining phenotypical variation (Figure 4). While the Sicilian population appears to be quite isolated as judging from the presence of an exclusive and highly frequent H1 haplotype and the lack of dispersal (see Bondì et al. 2018). Despite this presumed insular condition, Sicilian Peregrine Falcons show quite large deviation from the expected brookei 
E. Guzzo \& M. Sarà
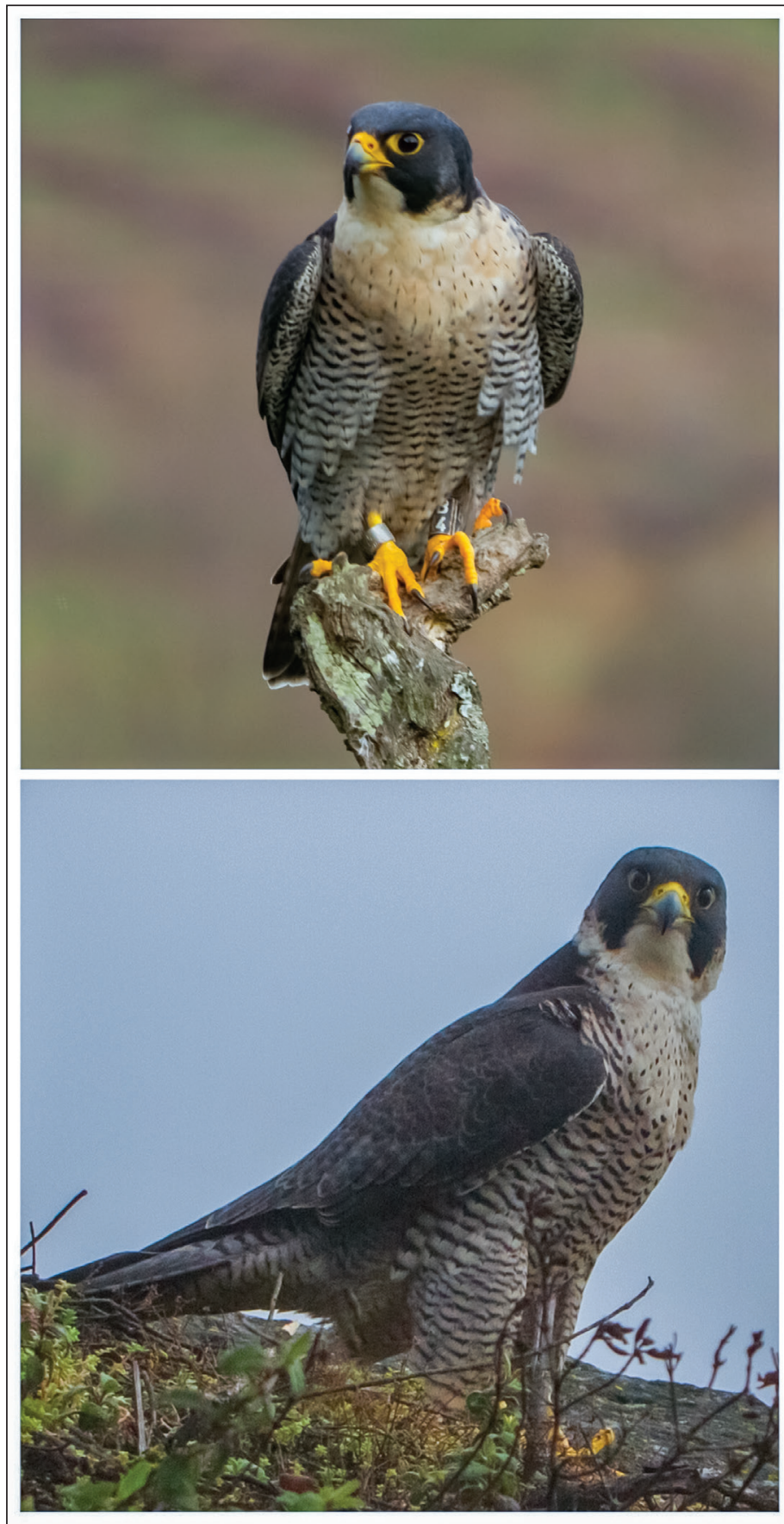

Figure 4. Individual phenotype variability of Biscay Peregrine Falcons. Above, a male brookei phenotype which is paired to a female peregrinus phenotype (below). Photo by Iñigo Zuberogoitia

4. ábra Egyedi fenotípusos változatosság a Biscay-i vándorsólymokban. Felül: hím brookei fenotípusú egyed, ami párt alkot egy tojó peregrinus (alul) fenotípusú egyeddel. Fotó: Iñigo Zuberogoitia 


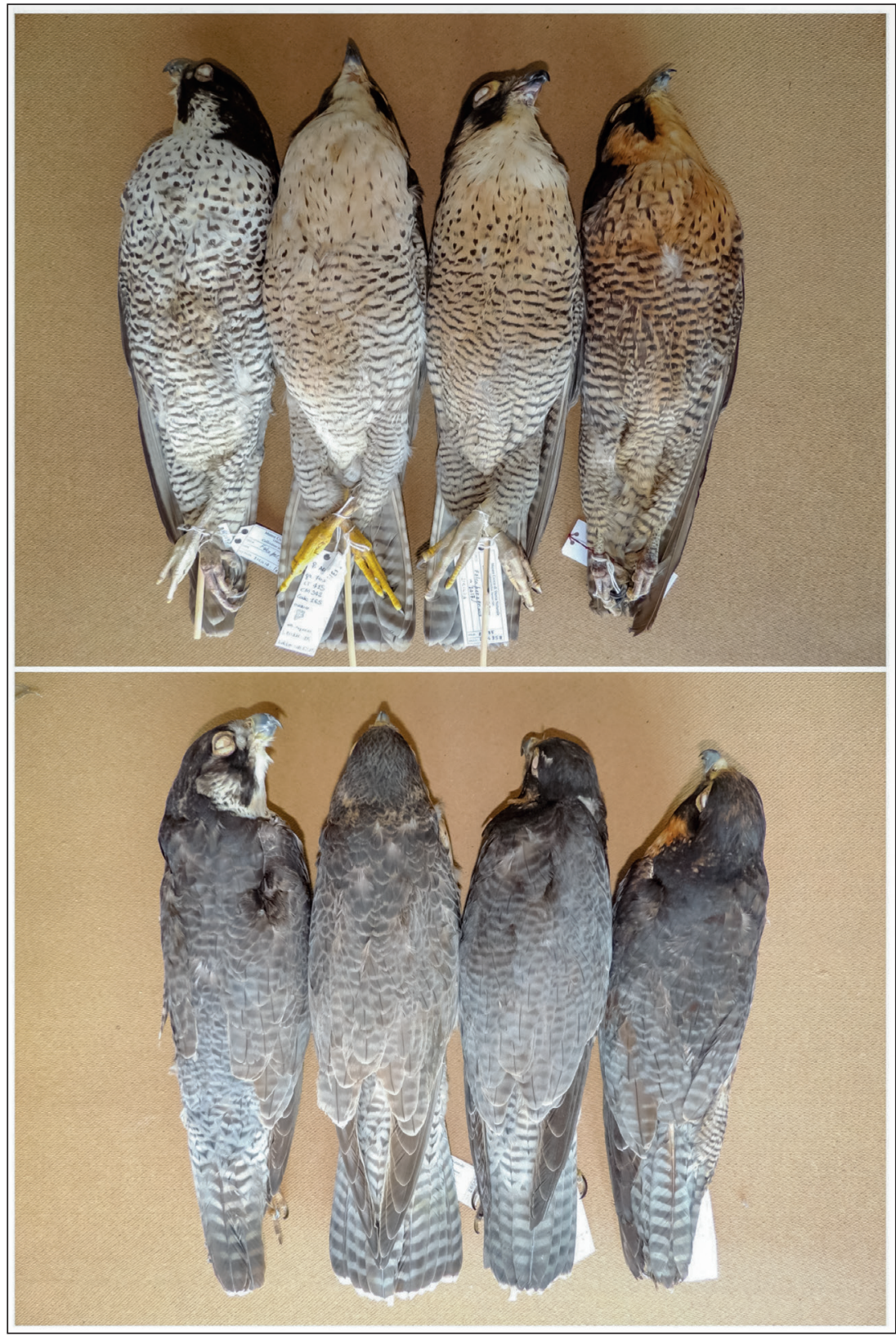

Figure 5. Individual phenotype variability of Sicilian Peregrine Falcons. Four adult females collected in different years and localities of Sicily arranged from the most F. p. peregrinus (left) to the most F. p. brookei (right) similar phenotype, above in ventral and below in dorsal view. Courtesy of Carmagnola Museum, Turin. Photo by Giovanni Boano

5. ábra Egyedi fenotípusos változatosság a szicíliai vándorsólymokban. Négy öreg tojó, amelyek különböző években és helyeken lettek gyűjtve Sziciliában F. p. peregrinus (bal) és F. p. brookei (jobb) jellegeket mutat. Felül hasi, alul háti nézetben. Carmagnola Museum, Torinó. Fotó: Giovanni Boano 


\section{E. Guzzo \& M. Sarà}

phenotype (Figure 5) and mitochondrial sequences consistent with continental populations that would admit gene flow with peregrinus populations. Further genomics analyses (e.g. Johnson et al. 2017) of both the Biscay and Sicilian and their neighbouring populations, together with natal dispersal studies may further clear these aspects.

\section{Acknowledgements}

We thank N. Antioco, S. Bondì, R. Mascara, A. Nardo, E. Vitale, L. Zanca for the great field support during the study in Sicily and M. Bryndová, J. Procházka, V. Šena, V. Šoltys who provided samples from the Czech Republic and I. Castillo, L. Astorkia, G. Burgos, M. Larrea who helped in the data collection of Spanish Peregrines. Funding was provided to M. Sarà by the Nando \& Elsa Peretti Foundation project no. 442, and to U. Tomas by Ministry of Education, Youth and Sports of the Czech Republic. This study complies with the current Italian laws regulating scientific research on animals.

\section{References}

Allavena, S. \& Brunelli, M. 2003. Revisione delle conoscenze sulla distribuzione e la consistenza del Pellegrino Falco peregrinus in Italia. Atti I Convegno Italiano Rapaci Diurni e Notturni. Preganziol (Treviso). - Avocetta 27: 20-23. (in Italian)

Bandelt, H. J., Forster, P. \& Röhl, A. 1999. Median-joining networks for inferring intraspecific phylogenies. - Molecular Biology Evolution 16:37-48. DOI: 10.1093/oxfordjournals.molbev.a026036

Bell, D. A., Griffiths, C. S., Caballero, I. C., Hartley, R. R. \& Lawson, R. H. 2014. Genetic evidence for global dispersal in the Peregrine Falcon (Falco peregrinus) and affinity with the Taita Falcon (Falco fasciinucha). - Journal of Raptor Research 48: 44-53. DOI: 10.3356/JRR-12-12.1

Belkhir, K., Borsa, P., Chikhi, L., Raufaste, N. \& Bonhomme, F. 1996-2004. GENETIX 4.05, logiciel sous Windows TM pour la génétique des populations. Laboratoire Génome, Populations, Interactions, CNRS UMR 5000, Université de Montpellier II, Montpellier (France)

Bondì, S., Guzzo, E., Mascara, R. \& Sarà M. 2018. Onset of natal dispersal in Peregrine Falcon from Mediterranean islands (Italy). - Ornis Hungarica 26(2): DOI:

Bryndová, M., Putnová, L., Bartoňová, P., Kaplanová, K. \& Urban, T. 2012. Genetic differences between wild and captive populations of the Peregrine Falcon (Falco peregrinus) and the Saker Falcon (Falco cherrug) Living in the Czech Republic. - Journal Agricultural Sciences Technology B 2: 642-651.

Bruford, M. W. \& Wayne, R. K. 1993. Microsatellites and their application to population genetic studies. - Current Opinions Genetics Development 3: 939-943. DOI: 10.1016/0959-437X(93)90017-J

Cade, T. J., Enderson, J. H., Thelander, C. G. \& White, C. M. 1988. Peregrine Falcon populations: their management and recovery. - Boise, Idaho

Ellegren, H. 1992. Polymerase-chain-reaction (PCR) analysis of microsatellites - a new approach to studies of genetic relationships in birds. - Auk 109: 886-895. DOI: 10.2307/4088163

Gainzarain, J. A., Arambarri, R. \& Rodríguez, A. F. 2002. Population size and factors affecting the density of Peregrine Falcon Falco peregrinus in Spain. - Ardeola 49: 67-74.

Goudet, J. 2001. FSTAT, a program to estimate and test gene diversities and fixation indices (version 2.9.3). Available from http://www.unil.ch/izea/softwares/fstat.html

Hall, T. A. 1999. BioEdit. A User-Friendly Biological Sequence Alignment Editor and Analysis Program for Windows 95/98/NT. - Nucleic Acids Symposium Series 41: 95-98. DOI: 10.1021/bk-1999-0734.ch008

Helbig, A. J., Seibold, I., Bednarek, W., Gaucher, P., Ristow, D., Scharlau, W., Schmidl, D. \& Wink, M. 1994. Phylogenetic relationships among falcon species (genus Falco) according to DNA sequence variation on the cytochrome-b gene. - In: Meyburg, B.-U. \& Chancellor, R. C. (eds.) Raptor Conservation Today. - World Working Group Birds of Prey and Pica Press, Berlin, pp. 593-599.

Horváth, M. B., Martinez-Cruz, B., Negro, J. J., Kalmár, L. \& Godoy, J. A. 2005. An overlooked DNA source for non-invasive genetic analysis in birds. - Journal of Avian Biology 36: 84-88. DOI: 10.1111/j.0908-8857.2005.03370.x 
Librado, P. \& Rozas, J. 2009. DnaSP v5 A software for comprehensive analysis of DNA polymorphic data. - Bioinformatics 25: 1451-1452. DOI: 10.1093/bioinformatics/btp187

Jacobsen, F., Nesje, M., Bachmann, L. \& Lifjeld, J. T. 2008. Significant genetic admixture after reintroduction of Peregrine Falcon (Falco peregrinus) in Southern Scandinavia. - Conservation Genetics 9: 581-591. DOI: 10.1007/ s10592-007-9373-4

Johnson, J. A., Talbot, S. L., Sage, G. K., Burnham, K. K., Brown, J. W., Maechtle, T. L., Seegar, W. S., Yates, M. A. $\&$ Mindell, D. P. 2010. The use of genetics for the management of a recovering population: temporal assessment of migratory Peregrine Falcons in North America. - PLoS ONE 5: e14042 DOI: 10.1371/journal.pone.0014042

Johnson, J. A., Novak, B. J., Kapp, J., Talbot, S. L., White, C. M., Nakajima, K., Shapiro, B. \& Anderson, B. 2017. Support for population structure in Peregrine Falcon subspecies revealed by low coverage nuclear genomes. - Abstract book $4^{\text {th }}$ International Peregrine Conference, Hermann Ottó Institute, Budapest

Nesje, M., Røed, K. H., Lifjeld, J. T., Lindberg, P. \& Steen, O. F. 2000a Genetic relationships in the Peregrine Falcon (Falco peregrinus) analysed by microsatellite DNA markers. - Molecular Ecology 9: 53-60. DOI: 10.1046/j.1365294x.2000.00834.x

Nesje, M., Røed, K. H., Bell, D. A., Lindberg, P. \& Lifjeld, J. T. 2000b Microsatellite analysis of population structure and genetic variability in Peregrine Falcons (Falco peregrinus). - Animal Conservation 3: 267-275. DOI: 10.1111/ j.1469-1795.2000.tb00112.x

Peakall, R. \& Smouse P. E. 2006. GenAlEx 6: genetic analysis in Excel. Population genetic software for teaching and research. - Molecular Ecology Notes 6: 288-295. DOI: 10.1111/j.1471-8286.2005.01155.x

Ponnikas, S., Ollilla, T. \& Kvist, L. 2017. Turnover and post-bottleneck genetic structure in a recovering population of Peregrine Falcons Falco peregrinus. - Ibis 159: 311-323. DOI: 10.1111/ibi.12460

Schenk, H., Chiavetta, M., Falcone, S., Fasce, P., Massa, B., Mingozzi, T. \& Saracino, U. 1985. The ecology of Peregrine Falcon in Italy: First results from five sample areas. - ICBP Technical Publications 5: 367-380.

Sibley, C. G. 1994. On the phylogeny and classification of living birds. - Journal Avian Biology 25: 7-92. DOI: $10.2307 / 3677024$

Talbot, S. L., Palmer, A. G., Sage, G. K., Sonsthagen, S. A., Swem, M. T., Brimm, D. J. \& White, C. M. 2011. Lack of genetic polymorphism among Peregrine Falcons Falco peregrinus of Fiji. - Journal Avian Biology 42: 415-428. DOI: 10.1111/j.1600-048X.2011.05280.x

Tamura, K., Peterson, D., Peterson, N., Stecher, G., Nei, M. \& Kumar, S. 2011. MEGA5: molecular evolutionary genetics analysis using maximum likelihood, evolutionary distance, and maximum parsimony methods. - Molecular Biology Evolution 28: 2731-2739. DOI: 10.1093/molbev/msr121

Topinka, R. J. \& May, B. 2004. Development of polymorphic microsatellite loci in the Northern Goshawk (Accipiter gentilis) and cross-amplification in other raptor species. - Conservation Genetics 5: 861-864. DOI: $10.1007 /$ s10592-004-1973-7

Tordoff, H. \& Reding, P. T. 2001. Role of genetic background in the success of reintroduced Peregrine Falcons. - Conservation Biology 15: 528-532. DOI: 10.1046/j.1523-1739.2001.015002528.x

Weir, B. S. \& Cockerham, C. C. 1984. Estimating F-statistics for the analysis of population structure. - Evolution 38: 1358-1370. DOI: $10.2307 / 2408641$

White, C. M., Cade, T. J. \& Henderson, J. H. (eds.) 2013a Peregrine Falcons of the World. - Lynx Edition, Barcelona

White, C. M., Sonsthagen, S. A., Sage, G. K., Anderson, C. \& Talbot, S. L. 2013b Genetic relationship among some subspecies of the Peregrine Falcon (Falco peregrinus L.), inferred from mitochondrial DNA control-region sequences. - The Auk 130: 78-87. DOI: 10.1525/auk.2012.11173

Wink, M., Seibold, I., Loftikhah, F. \& Bednarek, W. 1998. Molecular Systematics of Holoarctic Raptors (Order Falconiformes). - In: Chancellor, R., Meyburg, B.-U. \& Ferrero J. J. (eds.) Holoarctic Birds of Prey: Proceedings of an International Conference. - Adenex and World Working Group on Birds of Prey and Owls. IGRAEX C.B. Calamonte, Spain, pp. 29-48.

Wink, M., Döttlinger, H., Nicholls, M. K. \& Sauergürth, H. 2000. Phylogenetic relationships between Black Shaheen Falco peregrinus peregrinator, Red-naped Shaheen F. pelegrinoides babylonicus and Peregrines F. peregrinus. In: Chancellor, R. \& Meyburg, B.-U. (eds.) Raptors at risk: proceedings of $5^{\text {th }}$ World Conference on Birds of Prey and Owls. - World Working Group on Birds of Prey and Owls, Berlin, Germany, and Hancock House, Blaine, WA, USA, pp. 853-857.

Zuberogoitia, I., Azkona, A., Zabala, J., Astorkia, L., Castillo, I., Iraeta, A., Martínez, J. A. \& Martínez, J. E. 2009. Phenotypic variations of Peregrine Falcon in subspecies distribution border. - In: Sielicki, J. \& Mizera, T. (eds.) Peregrine Falcon populations - status and perspectives in the $21^{\text {st }}$ century. - Turul/Poznań University of Life Sciences Press, Warsaw - Poznań, pp. 295-308. 